\title{
High-resolution fisheries data reveal effects of bivalve dredging on benthic communities in stressed coastal systems
}

McLaverty, Ciaran; Eigaard, Ole R.; Dinesen, Grete E.; Gislason, Henrik; Kokkalis, Alexandros; Erichsen, Anders C.; Petersen, Jens Kjerulf

Published in:

Marine Ecology - Progress Series

Link to article, DOI:

$10.3354 / \operatorname{meps} 13330$

Publication date:

2020

Document Version

Peer reviewed version

Link back to DTU Orbit

Citation (APA):

McLaverty, C., Eigaard, O. R., Dinesen, G. E., Gislason, H., Kokkalis, A., Erichsen, A. C., \& Petersen, J. K. (2020). High-resolution fisheries data reveal effects of bivalve dredging on benthic communities in stressed coastal systems. Marine Ecology - Progress Series, 642, 21-38. https://doi.org/10.3354/meps 13330

\section{General rights}

Copyright and moral rights for the publications made accessible in the public portal are retained by the authors and/or other copyright owners and it is a condition of accessing publications that users recognise and abide by the legal requirements associated with these rights.

- Users may download and print one copy of any publication from the public portal for the purpose of private study or research.

- You may not further distribute the material or use it for any profit-making activity or commercial gain

- You may freely distribute the URL identifying the publication in the public portal 


\title{
High-resolution fisheries data reveal effects of bivalve dredging on benthic communities in stressed coastal systems
}

\author{
Ciarán McLaverty ${ }^{1,2, *}$, Ole R. Eigaard ${ }^{1}$, Grete E. Dinesen ${ }^{1}$, Henrik Gislason ${ }^{1}$, Alexandros \\ Kokkalis ${ }^{1}$, Anders C. Erichsen ${ }^{3}$, Jens Kjerulf Petersen ${ }^{2}$
}

\author{
${ }^{1}$ DTU Aqua, National Institute of Aquatic Resources, Technical University of Denmark, \\ Kemitorvet, 2800 Kgs. Lyngby, Denmark \\ ${ }^{2}$ Danish Shellfish Centre, Øroddevej 80, 7900 Nykøbing Mors, Denmark \\ ${ }^{3}$ DHI A/S, Agern Allé 5, 2920 Hørsholm, Denmark \\ *Corresponding author: cimc@aqua.dtu.dk
}

\begin{abstract}
Commercial dredging for blue mussels Mytilus edulis and oysters Ostrea edulis, Crassostrea gigas constitute the main bivalve fisheries in Denmark. These activities predominantly take place in Limfjorden, a large microtidal sound, and in the Inner Danish waters. Both areas are shallow, estuarine, receive high nutrient inputs from agriculture, and are of nature conservation interest (Natura 2000 sites), thus presenting challenges for an ecosystem approach to fisheries management. Using high-resolution fisheries data ( 10 m), we investigated the effects of bivalve dredging on benthic communities at both local (Natura 2000 site) and regional (fishery-wide) scales. Regionally, our results showed that dredging intensity correlated with shifts in species composition and reduced community biomass. We were, however, unable to detect an effect of dredging on community density, trait richness, and trait composition. These metrics were significantly related to other environmental drivers, such as sediment organic content (negative) and mussel bed biomass (positive). At the local scale, the observed relationships between dredging, biomass, and species composition varied significantly. This occurred as dredging impacts were greater in areas that contained suitable reference conditions and experienced relatively low levels of disturbance. By contrast, communities which experienced high nutrient loading, regular anoxic events, and high natural variability were relatively unaffected by dredging. Our results therefore highlight the importance of spatial scales in fishing impact estimations. Furthermore, we
\end{abstract}


demonstrate how targeted sampling, high-resolution fisheries data, and suitable reference areas can be used to detect fishery effects in coastal areas that are highly stressed by eutrophication.

KEY WORDS: Bottom trawling - Benthic macrofauna $\cdot$ Ecosystem-based management Bivalve fisheries $\cdot$ Spatial scales $\cdot$ Marine protected areas $\cdot$ Eutrophication $\cdot$ Mytilus edulis

\section{INTRODUCTION}

Bottom trawling accounts for nearly one-quarter of global seafood landings (FAO 2016), resulting in widespread disturbance to shelf sea habitats (Eigaard et al. 2017, Amoroso et al. 2018). Balancing the effects of such activities on the ecosystem with sustainable exploitation of marine resources forms the basis of an ecosystem approach to fisheries management (Gislason et al. 2000). For bottom trawl and dredge fisheries, this has meant an increased focus on impacts to seabed biota, ecological function, benthic production, and interactions with higher trophic levels (Jennings et al. 2002, Tillin et al. 2006, Olsgard et al. 2008, Hinz et al. 2017, Sciberras et al. 2018).

Dredges are a type of towed fishing gear primarily used in scallop, oyster, and blue mussel fisheries (FAO 2016). Although relatively compact and of low spatial footprint, dredges can weigh up to several hundred kilograms (Eigaard et al. 2016). Dredging is therefore characterised by deeper sediment penetration than other forms of trawling (Hiddink et al. 2017). Nonetheless, the effects of dredging on benthos can vary considerably by habitat type or environment setting. Dredging in vulnerable habitats, such as circalittoral biogenic reefs, can be particularly damaging and result in substantial declines in associated benthic species and long recovery times (Hall-Spencer \& Moore 2000, Kaiser et al. 2006, Cook et al. 2013). Conversely, dredging in nearshore sedimentary habitats, which experience high natural disturbance, can result in negligible or short-term impacts (Sciberras et al. 2013, Moritz et al. 2015, Szostek et al. 2016, Lambert et al. 2017). Such variable outcomes can occur as ecological communities, and their associated life history traits, are well adapted to ambient environmental conditions. Under high environmental disturbance, traits such as short lifespans, high mobility, and fast population growth ( $r$-strategists) are more common, while large body size, slow growth, and late maturity traits are rarer ( $K$-strategists) (MacArthur \& Wilson 1967). Bottom trawling disturbance also modifies trait composition in a similar 
manner (Tillin et al. 2006, de Juan \& Demestre 2012, Kaiser et al. 2018), and as a result, benthic communities found in areas of high natural disturbance can closely resemble those in heavily trawled areas (Jennings \& Kaiser 1998, Diesing et al. 2013, van Denderen et al. 2015, Szostek et al. 2016).

In Denmark, infralittoral populations of blue mussel Mytilus edulis (Linnaeus, 1758) (hereafter referred to as mussels), European flat oyster Ostrea edulis (Linnaeus, 1758), and Pacific oyster Crassostrea gigas (Thunberg, 1793) (both hereafter referred to as oysters) are exploited in Limfjorden and the Inner Danish waters (see Fig. 1). These areas are similar to many other Danish estuaries; i.e. they are predominantly shallow and brackish and experience short residence times, variable physico-chemical conditions, and high levels of eutrophication (Conley et al. 2000). Over the last century, nitrogen and phosphorous loadings have increased 6-fold in some areas (peaking in the 1980s) as a result of intensified agriculture (Tomczak et al. 2013). In Limfjorden, significant reductions in water quality have been linked to the collapse of commercial finfish fisheries (Hoffmann \& Dolmer 2000), regime shifts (Tomczak et al. 2013), and a concurrent increase in bivalve biomass (Maar et al. 2010). While loadings have declined in recent years, long-running and regular anoxic and hypoxic events persist in some areas (Jørgensen \& Jorgensen 1980, Conley et al. 2000), leading to the intermittent mass mortality of bivalve stocks and associated benthos (Dolmer et al. 1999). These considerable environmental and ecological changes, combined with the emergence of a significant dredge fishery, has led to increased political and public focus on the effect of these fisheries on ecosystems (Dolmer \& Frandsen 2002) and the requirement for evidence-based management and advice.

Dredging in these coastal areas is known to impact local sediment biogeochemistry (Riemann \& Hoffmann 1991) and physically removes hard substrates (shells, stones, live mussel matrix) required for mussel recruitment and juvenile survival (Dolmer \& Frandsen 2002). However, the effects on benthic macrofauna are generally thought to be short-term. Experimental dredging trials in Limfjorden have reported increased densities of scavenging brown shrimps Crangon crangon in the days immediately post-dredging, and reduced species richness for up to $40 \mathrm{~d}$ after dredging (Dolmer et al. 2001). Conversely, some comparative studies have reported similar epibenthic communities in unfished and fished areas (Hoffmann $\&$ Dolmer 2000), although densities of the large suspension feeding plumose anemone Metridium senile have been shown to be comparatively higher in unfished areas (Riis et al. 2003). While these small-scale studies have provided the basis for scientific understanding to 
date, little is known about the ecosystem effects of commercial dredging across the fishing grounds, and how benthic macrofauna are affected along gradients of fishing disturbance in these dynamic systems.

A particular issue with this knowledge gap is that the fishing grounds overlap with several Natura 2000 (N2000) sites. These areas are designated under the EU Birds Directive (Anon 1979) and Habitats Directive (Anon 1992) to protect designated features such as sandbanks, reefs, large shallow inlets and bays, as well as several protected vertebrate species (e.g. harbour seal Phoca vitulina Linnaeus, 1758 and a number of mussel-eating and wading birds). In response to this issue, the Danish Mussel Policy was set up in 2013 to regulate and sustainably manage fisheries in these areas (Ministry of Foreign Affairs of Denmark 2019). This brought about management strategies designed to reduce dredging impacts to designating features, including exclusion zones in areas $\leq 3-5 \mathrm{~m}$ deep (site dependent) and in vulnerable habitats i.e. eel grass Zostera marina beds and boulder reefs. Furthermore, fishing is restricted to areas with mussel densities $\geq 1 \mathrm{~kg} \mathrm{~m}-2$ (Frandsen et al. 2015), licences are limited (52 in Limfjorden; 8 in the Inner Danish waters), and vessels are only permitted to cumulatively impact up to $15 \%$ of the seabed within each N2000 site. To ensure compliance with these regulations, all dredging activities in N2000 sites have been conditional on the use of 'black-box' devices since 2012 in Limfjorden, and 2013 east of Jutland. The devices monitor fishing effort by logging vessel position, speed, and winch activity every $10 \mathrm{~s}$. This represents an unusually high temporal and spatial resolution for fisheries data, given that the Vessel Monitoring Systems (VMS) used in the EU are typically restricted to an hourly polling frequency. The availability of such high-resolution fisheries data thus allows for the examination of research questions at much finer spatial scales than previously possible. The relevance of this is that relationships between ecological systems and environmental processes are often scale- dependent (Wiens 1989), and therefore a potentially important consideration in the estimation of benthic mortality from bottom trawl fisheries (Piet \& Quirijns 2009).

The aim of this study was to investigate the effects of dredging on benthic communities in fishing grounds that experience high levels of eutrophication and natural variability. To achieve this goal, we used black-box data to examine potential effects at both local (N2000 sites) and regional (fishery-wide) scales. We collected macrofaunal data from 34 locations across the main bivalve grounds in Denmark and examined the effects of dredging on taxonomic and functional (biological trait) characteristics. The analysis accounts 
for environmental differences between fishing grounds as well as sediment characteristics and hydrodynamic properties. Our findings provide new evidence regarding the ecosystem effects of dredging in estuarine and eutrophic systems, and are expected to be of particular relevance to management of fisheries in coastal waters.

\section{MATERIALS AND METHODS}

\subsection{Study area}

\subsubsection{Limfjorden}

The N2000 sites 'Nissum Broad' (hereafter Nissum), 'Lovns Broad' (hereafter Lovns), and 'Løgstør Broad, Livø, Feggesund and Skarrehage' (hereafter Løgstør) are located within Limfjorden, a large microtidal sound $\left(1500 \mathrm{~km}^{2}\right)$ open to North Sea in the west and the Kattegat in east (see Fig. 1). The area is physically and hydrodynamically complex and is predominantly shallow, with a mean depth of $\sim 5 \mathrm{~m}$ and maximum depth of $24 \mathrm{~m}$. Salinity decreases from $\sim 34$ PSU in the west to 26 PSU in the east (Tomczak et al. 2013), and is locally influenced by large seasonal freshwater influxes. Water temperatures fluctuate considerably between ice cover and $>25^{\circ} \mathrm{C}$ during the summer, while surface and bottom currents are predominantly wind-driven. The area is also eutrophic due to nutrient-rich runoff from a $7500 \mathrm{~km}^{2}$ watershed (Dolmer et al. 1999), causing reduced water quality and seasonal hypoxia and anoxia (Maar et al. 2010). Despite these water quality issues, a highly productive mussel fishery is located in central Limfjorden. The majority of landings come from Lovns and Løgstør, and reached a peak of $\sim 100000 \mathrm{t} \mathrm{yr}^{-1}$ in the late 1990s (Dinesen et al. 2011). Since then, mussel biomass has declined and increased fisheries regulations have seen present day landings fall to roughly 30000-40000 $\mathrm{t} \mathrm{yr}^{-1}$. Mussels are fished within the N2000 areas using a modified 'light' Dutch dredge. This gear is lighter $(\sim 120 \mathrm{~kg})$ than the traditional Dutch dredge $(\sim 230 \mathrm{~kg})$, resulting in reduced drag and sediment resuspension (Frandsen et al. 2015). Fisheries for European flat oyster Ostrea edulis have operated in Nissum for over 100 yr. Today, oyster fisheries in Nissum and Løgstør also target Pacific oyster Crassostrea gigas. Oyster landings are considerably smaller than that of mussels, peaking at $1489 \mathrm{t}$ in 2008 (with a stock biomass >10000 t) (Nielsen \& Petersen 2019). In recent years the fishery has been restricted, and the total allowable catch was $129 \mathrm{t}$ in 2016 (with a stock biomass $2000 \mathrm{t})$. Oyster dredges used in N2000 areas are considerably lighter ( $35 \mathrm{~kg})$ and smaller than the dredges used in the mussel fishery (Dolmer \& Hoffmann 2004). To protect 
vulnerable eelgrass habitats, the northern parts of the Løgstør N2000 site have been closed to bottom fishing since 1988 (Kristensen \& Hoffmann 1999).

\subsubsection{Inner Danish waters}

The N2000 site 'Horsens Fjord and the sea east of Endelave' (hereafter Horsens) is located along the eastern coast of Jutland in the Inner Danish waters (see Fig. 1). It comprises an area of $\sim 458 \mathrm{~km}^{2}$ and extends from the mouth of Horsens Fjord east into the southern Kattegat. The site ranges from shallow ( $\sim 3 \mathrm{~m})$ estuarine and heavily eutrophic waters in the west to deeper ( $20 \mathrm{~m}$ ) and more marine conditions in the east (Markager et al. 2010). Similarly to Limfjorden, Horsens has supported significant mussel fisheries since the late 1990s, when landings peaked at $20000 \mathrm{t} \mathrm{yr}^{-1}$. However, no fisheries operated in Horsens between 2007 and 2016. The resumption of fisheries in the 2016-2017 season yielded landings of $12012 \mathrm{t}$, from an estimated mussel biomass of $160000 \mathrm{t}$ (Nielsen et al. 2017). Incidentally, that fishing season took place in the year prior to benthic sampling, meaning that large areas of Horsens had been unfished (see Fig. 1D) for a minimum of $10 \mathrm{yr}$ before data for this study were collected.

\subsection{Sampling design}

Sampling effort was distributed equally between unfished and dredged areas within each basin. This method was undertaken to account for the low spatial extent of fishing effort and the expected variation in the benthos across treatments. Using composite GIS maps, we selected sampling locations based on the following criteria: (1) dredged seabed (impacted $\leq 1.5 \mathrm{yr}$ prior to sampling in April 2017) (described in Section 2.5); (2) unfished seabed (unimpacted since 2012 and $\geq 100 \mathrm{~m}$ away from fished areas); (3) mud and sandy mud habitat (determined from habitat maps provided by the Danish Shellfish Centre); (4) $\leq 3 \mathrm{~m}$ depth range (within a given basin); (5) presence of mussel/oyster beds (using bivalve density maps provided by the Danish Shellfish Centre; see Fig. 1); (6) absence of seabed anoxia (between 2016 and April 2017) (using maps provided by the Danish Centre for Environment and Energy: http://bios.au.dk/raadgivning/vand/havmiljoe/iltsvind/arkiv/). As mussel beds can enhance benthic diversity (Norling \& Kautsky 2008), we deployed a camera transect at each site to determine mussel bed cover. This ensured that stations in unfished areas composed of bare sand were moved or excluded. To account for potential differences in mussel beds between sites, we included mussel biomass (in g ash-free dry weight) as a predictor in the 
analysis. Tests for collinearity confirmed that mussel biomass was not confounded with other predictors, such as fishing effort. Although mussels occur in Nissum, they are generally sparse and do not form significant or consolidated subtidal beds. Therefore, the bivalve bed criterion was not applied in this basin, and sampling sites were selected based on fishing effort, sediment type, and depth.

\subsection{Data collection and sample processing}

A total of 34 sites were sampled between April and June 2017 (Horsens: 8; Løgstør: 10; Lovns: 8; Nissum: 8) (see Fig. 1A-D). Prior to grab sampling, a camera transect comprising $10 \mathrm{~min}$ at $0.6-0.8$ knots, or roughly $200 \mathrm{~m}$, was deployed at each site to identify mussel beds. A total of 5 replicate grab samples were obtained within the beds using a $0.1 \mathrm{~m}^{2}$ Van-Veen grab sampler. In total, 4 replicates were analysed for benthic macrofauna, while the fifth was used to determine sediment grain size and organic content. Macrofaunal samples were sieved over a $1 \mathrm{~mm}$ mesh and preserved in $4 \%$ formalin seawater solution buffered with borax (sodium borate). In the laboratory, the residuum was rinsed, sorted, and all animal material identified to the lowest taxonomic level possible. Biomass estimates were determined via ash-free dry weight. The nomenclature of all taxa were validated and standardised in accordance with the World Register of Marine Species (WoRMS Editorial Board 2018; correct as of 05/01/2019). Sediment particle size analysis (PSA) was undertaken via mass loss following wet sieving (Danish Standard [DS] 405.9), resulting in the estimation of the percentage of mud $(<63 \mu \mathrm{m})$, sand $(0.063-2 \mathrm{~mm})$, and gravel $(\geq 2 \mathrm{~mm})$. Organic content was calculated via percentage loss-on-ignition (LOI) by estimating the mass loss of 4 $\mathrm{mg}$ of homogenised sediment placed in a muffle furnace at $560^{\circ} \mathrm{C}$ for $4 \mathrm{~h}$, or until a constant weight was achieved (DS 204). During data collection it was observed that sediment samples often contained large quantities of shell hash (empty shells and fragments). Therefore, all shell hash $>4 \mathrm{~mm}$ were weighed in the laboratory, and the weight was used as a predictor in the analysis. In some areas, large numbers of Asterias rubens and Carcinus maenas were sampled. Both species are relatively mobile members of the macrofauna, and feed in high densities on mussel beds (Frandsen \& Dolmer 2002). In particular, large numbers of $A$. rubens can aggregate and periodically swarm mussel beds in Limfjorden (Dolmer 1998). We therefore undertook permutation-based tests of homogeneity of dispersions (PERMDISP; Anderson et al. 2008) with and without these species. This revealed significant multivariate dispersion between the different basins when A. rubens and C. maenas were included in 
biomass estimates (PERMDISP, $F=2.9176, \mathrm{p}=0.037$ ). A. rubens and $C$. maenas were therefore removed to improve the statistical results, and because their abundances estimated from a one-off sampling event may be unrepresentative of dredging activities calculated at annual scales. For completeness, we provide the results for community biomass including $A$. rubens and C. maenas in Table S3 \& Fig. S3 in the Supplement at www.intres.com/articles/suppl/mXXXpXXX_supp.pdf. Due to the focus of sampling effort on bivalve beds, the target species of the fishery (i.e. Mytilus edulis) were also excluded from the analysis.

\subsection{Biological traits}

To describe the functional structure of the community, we calculated the trait composition of the macrofauna in each sample. This was done using an existing fuzzy coded trait database complied by Bolam et al. (2017). The database describes 10 trait categories relating to size, longevity, larval development, morphology, egg development, living habit, sediment position, feeding mode, mobility, and bioturbation. The information is fuzzy coded using 48 descriptive modalities, which are described in detail in Bolam et al. (2017). Prior to analysis, the modality scores were standardised within each trait category and then combined with biomass data.

\subsection{Estimation of dredging intensity}

Dredging intensity was estimated as swept-area ratio (SAR) values. To calculate SAR values, we aggregated the total dredged (or swept) area within a $10 \mathrm{~m}$ radius around each benthic sampling position using black-box data. The SAR values equate to the accumulated dredged area within this circle, divided by the area of the circle. SAR can therefore be interpreted as the numbers of times the seabed was dredged during the study period. For the purposes of this study, black-box data were filtered and fishing activity defined as (1) when vessel speed is between 1.5 and 4.0 knots, (2) this speed interval is met for at least $80 \mathrm{~s}(8$ consecutive loggings), and (3) when these loggings match registered winch activity. Blackbox data were combined with logbook information to determine gear configuration (type and size of dredge; number of dredges) and footprint. The black-box data were provided at a precision of $2 \mathrm{~m}$ under optimal conditions, although this varied $(2-10 \mathrm{~m})$ depending on sea conditions and location. As the mussel fishing season is closed annually during JanuaryFebruary and June-August each year, we aggregated fishing data over $1.5 \mathrm{yr}$ prior to 
sampling to account for the closed periods. For ease of interpretation, SAR values are presented as equivalent values $\mathrm{yr}^{-1}$.

\subsection{Natural and anthropogenic drivers}

Due to the expected influence of anthropogenic and natural pressures, we gathered information on hydrodynamic (salinity, temperature, current velocity), physical (sediment grain size, depth, mussel biomass, and shell hash) and anthropogenic (nutrient loading) parameters. Data regarding depth, LOI, sediment mud content, mussel biomass, and shell hash were collected in the field. Hydrodynamic data in the form of bottom current velocity, bottom salinity, bottom temperature (mean + range for each) were extracted from the MIKE 3 HD Flexible Mesh (FM) models (DHI 2013) (see Text S1 in the Supplement for more information). The hydrodynamic models were calibrated to consider the specific hydrodynamic conditions of Limfjorden and Inner Danish waters. This was done using an unstructured flexible mesh and finite volume solution technique provided by MIKE 3 FM, which allows for variation in the horizontal resolution of the model grid mesh. As a result, the hydrodynamic data were provided at spatial resolutions of between 100 and $1000 \mathrm{~m}$ for Limfjorden, and between 40 and $400 \mathrm{~m}$ for Horsens. Hydrodynamic data were estimated at each sampling site at a monthly scale and averaged over 2016.

\subsection{Data analysis}

\subsubsection{Predictor variables}

In addition to the predictors listed in Sections 2.5 and 2.6, the categorical variable basin was included in the analysis to capture auxiliary sources of variation potentially not described by the other variables. This resulted in 13 predictor variables: dredging intensity, bottom salinity (mean and range), bottom temperature (mean and range), bottom current velocity (mean and range), mud content, LOI, depth, mussel biomass, shell hash, and basin. The variables dredging intensity, mussel biomass, and shell hash were log transformed $\left(\log _{\mathrm{e}}\right.$ $+1)$ to reduce the weighting of outliers and normalise skewed distributions. Prior to formal statistical analysis, all potential predictors were checked for multicollinearity. Pair-wise plots were used to calculate correlation coefficients; those $>0.7$ were excluded from further analysis (Dormann et al. 2013) (Fig. S1in the Supplement). Bottom temperature range ( $\mathrm{r}=$ $0.858)$, bottom temperature mean $(r=0.741)$, and bottom current velocity range $(r=0.781)$ were excluded as they were collinear with depth. Bottom salinity range $(r=0.797)$ and 
bottom salinity mean $(r=0.776)$ were also excluded as collinear with basin, while sediment grain size (mud content) was excluded as collinear with LOI $(\mathrm{r}=0.771)$. As salinity was expected to be a potentially important predictor, we verified the choice to exclude this term by examining model fits with either the salinity (mean/range) or basin included term. In each case, models containing the categorical basin term had lower Akaike's information criterion (AIC) values. Variance inflation factor (VIF) values were checked for the remaining 7 predictors (basin, mean bottom current velocity [current], depth, dredging, LOI, mussel biomass, and shell hash) to assess multicollinearity prior to analysis (Table S1 in the Supplement). While some level of correlation was present across the remaining predictors, the VIFs were all below the acceptable threshold of 5 (Kutner et al. 2004).

\subsubsection{Habitat comparability}

To ensure comparability of environmental conditions at local and regional scales, analyses of similarity were undertaken using multivariate clustering analysis, using the package PRIMER v.7 (Clarke \& Gorley 2015). Clustering of predictor variables (excluding dredging intensity) were based on normalised Euclidean distances. Significance was determined using the SIMPROF routine, which tests for statistically significant site clusters. At the regional scale, the analysis resulted in 4 distinct clusters based on each basin. To account for potential differences in habitat type, we therefore forced the inclusion of basin in the calculation of all statistical models at the regional scale. At the local scale, the analysis resulted in a single cluster for each basin (Fig. S2 in the Supplement).

\subsubsection{Univariate analysis: community indicators}

Generalised linear mixed models (GLMMs) were used to model 3 community indicators: density, biomass, and functional richness, chosen based on their sensitivity to trawling disturbance in Danish waters (McLaverty et al. 2020). Density and biomass were calculated as the total number and biomass of individuals in a sample, respectively. Functional richness describes the richness of traits expressed in the community, measured by the total volume of multivariate trait space occupied by the community, and ranges from 0 to 1 (Villéger et al. 2008). Each model included a site-specific random term to account for the non-independence of replicate samples at each site. Community biomass was log transformed, and indicators were modelled using either a negative binomial (density), Gaussian (biomass), or beta (functional richness) distribution. To estimate the relative effects 
of each predictor, we calculated the relative variable importance (RVI) of each predictor via multi-model inference using the R package 'MuMin' (Barton 2013). This method quantifies the importance of each predictor regardless of significance level. RVI values are determined from the weighted AIC, calculated across all permutations of a global model (Burnham \& Anderson 2002). These can be interpreted as highly important (RVI > 9), moderately important $(\mathrm{RVI}>0.6)$, low importance $(\mathrm{RVI}<0.6)$, and little/no importance $(\mathrm{RVI}<0.5)$. In addition, statistical significance and the direction of the relationship (i.e. negative or positive) were calculated via a model averaging function, using the 'MuMin' package (Barton 2013). Averaging was carried out across models which had substantial support (i.e. those models with $\triangle \mathrm{AIC}<2$; Burnham \& Anderson 2004). GLMM diagnostics were checked via a simulation-based approach suited for mixed models using the R package 'DHARMa' (Hartig 2016); GLMMs were fit using the R package 'glmmTMB' (Brooks et al. 2017). To streamline the analysis, we included the interaction term basin $\times$ dredging. A significant interaction term would indicate whether the relationship between indicators and dredging varied at the basin scale. The marginal effects and interaction terms of GLMMs were plotted using the 'sjPlot' package (Lüdecke 2016). All univariate analyses were carried out using R v.3.6.0 (R Development Core Team 2019)

\subsubsection{Multivariate analysis: community composition}

Distance-based linear models (DistLMs) were used to analyse the effect of predictor variables on 3 estimates of community composition: density-based species composition, biomass-based species composition, and trait composition. This approach provided an analogous approach to the univariate indicators used at the regional scale. DistLMs are based on a distance-based redundancy analysis (dbRDA) (Legendre \& Andersson 1999), which models the relationship between a multivariate response and environmental predictors. The approach partitions variance in the response variable among the predictors. Model selection was undertaken using the 'step-wise' selection procedure, and p-values were obtained based on 999 permutations. Selection of the final model was based on AIC for small sample sizes $\left(\mathrm{AIC}_{\mathrm{C}}\right)$. Density was fourth-root transformed and biomass data were log transformed prior to analysis. Resemblance matrices of taxonomic and trait data were calculated based on BrayCurtis similarity, using Euclidean distance for environmental data. At the local scale, we tested for differences in community composition between fished and unfished areas using a 2-way crossed permutational multivariate analysis of variance (PERMANOVA) design, with basin and dredging as factors. If significant, post hoc tests using pair-wise PERMANOVA 
and similarity percentage breakdowns (SIMPER) identified the species or traits which made the greatest contribution to the observed dissimilarity. PERMANOVA models were based on 999 permutations of residuals under a reduced model, using Type III (partial) sums of squares (SS) to account for the asymmetry in the sampling design. All multivariate analyses were carried out using PRIMER v.7 with PERMANOVA+ (Anderson et al. 2008).

\section{RESULTS}

\subsection{Dredging effort}

The distribution of dredging effort over the study period was confined to relatively small areas within each basin (Fig. 1A-D). Dredging generally took place at intermediate water depths i.e. seaward of the 0-3 m restricted zone, and away from deeper areas which may suffer low oxygen conditions. Dredging intensity (i.e. SAR) was relatively uniform between Løgstør (mean SAR: 2.17), Nissum (mean SAR: 2.52), and Lovns (mean SAR: 1.42). Conversely, the dredging intensity in Horsens (mean SAR: 10.22) was approximately 4-5 times higher than the other areas. A summary of dredging intensity and environmental variables for each sampling is provided in Table S2 in the Supplement.

\subsection{Macrofaunal community}

A total of 2004:2 individuals, 160 taxa, and 13 main phylogenetic groups were recorded across the 34 sampling sites. These groups included Polychaeta (71 taxa), Malacostraca (26), Bivalvia (22 taxa), Gastropoda (20 taxa), Echinodermata (8 taxa), Clitellata, Polyplacophora, Ascidiacea, Hexanauplia (all represented by 2 taxa), and a single taxon within the Anthozoa, Nemertea, Phoronida, and Pycnogonida. Mussels Mytilus edulis dominated measures of density and biomass (Table 1). The occurrence of mussels in dredged and unfished areas was largely similar ( $\sim 51$ and $\sim 55 \%$, respectively). Camera transects revealed that bivalve beds were highly variable in coverage, ranging from large consolidated beds (e.g. Løgstør), to mosaics of fragmented beds (e.g. Horsens), to a sparse coverage of individuals (both mussel and oysters) (e.g. Nissum). Dominant taxa included deposit feeding polychaetes (Streblospio shrubsolii, Capitella sp.), bivalves (Petricolaria pholadiformis, Kurtiella bidentata), a deposit feeding gastropod (Peringia ulvae), small crustaceans (Microdeutopus sp., Monocorophium insidiosum), and 2 taxa within the subclass Oligochaeta 
(Tubificoides benedii and Oligochaeta indet.). In general, the most abundant taxa were also widely occurring (e.g. S. shrubsolii and K. bidentata were present in $>80 \%$ of samples). On the other hand, biomass was dominated by fewer taxa that exhibited lower spatial coverage. These included relatively large and long-lived bivalves (Arctica islandica, Modiolus modiolus, $P$. pholadiformis, Venerupis corrugata), scavenging and deposit feeding gastropods (Tritia reticulata, Aporrhais pespelecani, P. ulvae, Littorina littorea), and larger predatory polychaetes (Alitta virens and Nephtys hombergii).

\subsection{Regional effects of dredging: community indicators}

The RVI scores indicated that spatial patterns in density were best explained by sediment organic content (i.e. LOI) (RVI: 0.96), mussel biomass (RVI: 0.93) and shell hash (RVI: 0.68) (Table 2). LOI demonstrated a negative relationship with density (Fig. 2D), while relationships with mussel biomass (Fig. 2B) and shell hash (Fig. 2C) were positive. Basin (RVI: 1) was a significant term in the most parsimonious model for density (Fig. 2A); however, the RVI score of 1 (in each model) is due to its forced inclusion in all permutations of the global model. Dredging and density exhibited a positive although non-significant trend (RVI: 0.36) (Table 2). In contrast, dredging and biomass exhibited a significant negative relationship (RVI: 0.62) (Fig. 2E). A significant positive relationship was also observed between shell hash and biomass (RVI: 0.71) (Fig. 2F). Although the interaction between basin and dredging was significant (discussed in Section 3.5), basin was not significant in the final biomass model (Table 2). Basin (RVI: 1; Fig. 2G) and mussel biomass (RVI: 0.99; Fig. $2 \mathrm{H})$ were the only significant predictors in the final model of functional richness. Functional richness also demonstrated a non-significant negative trend with dredging (RVI: 0.27).

\subsection{Local effects of dredging: community indicators}

The interaction term in the biomass model (RVI: 0.49) revealed that the relationship between dredging and biomass varied significantly among basins (Fig. 2I). In Horsens and Løgstør, the relationship was similar to the overall trend observed at the regional scale (Fig. $2 \mathrm{~F}$ ), indicating the importance of these basins in the regional assessment. Conversely, biomass showed little variation as a function of dredging in Nissum, and exhibited a positive relationship with dredging in Lovns (Fig. 2I). The predicted values at the higher dredging intensities were characterised by high uncertainty (indicated by $95 \% \mathrm{CIs}$ ). This was due to a relative lack of observations, e.g. dredging intensity did not exceed $2.58 \mathrm{SAR} \mathrm{yr}^{-1}$ in Lovns. 


\subsection{Regional effects of dredging: community composition}

Table 3 outlines the percentage of community variance allocated to predictors by the DistLMs. In each case, the majority of explained variance was accounted for by basin. This was particularly the case for density-based composition (21.3\%) and trait based-composition $(10.4 \%)$, whereas biomass was relatively similar across basins $(7.5 \%)$. Variance in species and trait composition was significantly linked to depth (density $=9.5 \%$, biomass $=4.9 \%$, traits $=2.4 \%$, mussel biomass (density $=5.4 \%$, biomass $=2.4 \%$, traits $=4.2 \%$, and shell hash $($ density $=3.3 \%$, biomass $=2.1 \%$, traits $=4.2 \%)$. Dredging $($ density $=3.3 \%$, biomass $=$ $2.95 \%)$ and LOI (density $=5.5 \%$, biomass $=3.3 \%$ ) were significant predictors of species composition, with no observed effect on trait composition.

\subsection{Local effects of dredging: community composition}

A significant interaction term was observed in the models of density-based (pseudo- $F$ $=3.25, \mathrm{p}=0.001$ ) and biomass-based (pseudo- $F=2.11, \mathrm{p}=0.001$ ) species composition (Table 4), indicating differences between unfished and fished areas varied by basin. Post hoc pairwise comparisons revealed that density varied between unfished and dredged areas in each of the 4 basins. The marginally larger pseudo- $t$ values in Horsens (pseudo- $t=2.33$ ) and Lovns (pseudo- $t=2.2$ ) indicated that differences were greater in these basins. In the case of biomass-based composition, the community varied significantly in each basin except Nissum (pseudo- $F=1.2, \mathrm{p}=0.134$ ). No differences were detected in trait composition between unfished and dredged areas.

The taxa that contributed most to the observed differences are presented in Table 5. In terms of density, several of these taxa exhibited opposing trends, either within basins (e.g. Horsens) or between basins (e.g. Løgstør and Lovns). However, the densities of sedentary taxa (e.g. Prionospio fallax, S. shrubsolii, Phoronis sp., K. bidentata, Galathowenia oculata) were typically reduced in dredged areas. Similarly consistent responses were observed for the predatory polychaetes Pholoe inornata and Kefersteinia cirrhata, and the amphipod Microdeutopus sp. On the other hand, mobile gastropods (Bittium reticulatum, P. ulvae, and Odostomia sp.), and opportunistic oligochaetes (T. benedii and Oligochaeta indet.) were recorded at higher densities in the dredged areas. The trends observed for biomass were more consistent within basins, and reflected the relationships observed for the community biomass indicator. Large-bodied taxa were characteristic of the unfished areas of Horsens and Løgstør and included A. islandica, A. virens, Nephtys caeca, and Psammechinus miliaris. Conversely, 
a higher biomass composed of $P$. pholadiformis, $P$. ulvae, and Mya arenaria was observed in the dredged areas of Lovns.

\section{DISCUSSION}

Our results suggest that dredging reduced community biomass and impacted species composition across the study area. Nonetheless, these relationships varied significantly between regional and local scales, and several of the benthic metrics examined in the study did not show a response to dredging. These findings therefore demonstrate how eutrophication and natural disturbance can partly mask the effects of dredging on benthic communities. Nonetheless, the availability of suitable reference conditions and highresolution dredging data undoubtedly benefited our analysis, and illustrates the potential importance of these aspects for fishery impact assessments in coastal areas. In the following sections, we elaborate on our findings and discuss implications from an ecological and management standpoint.

\subsection{Regional effects of dredging}

Community biomass decreased exponentially over the gradient of dredging intensity, as indicated by the log-log linear relationship in Fig. 2E. This relationship is frequently observed as the initial passes of a trawl are disproportionately damaging to the benthos, and result in a greater relative loss than successive passes (Hiddink et al. 2006). While there was relatively high variation in biomass at the unfished and lightly fished sites, biomass was consistently low at frequencies of SAR $>5 \mathrm{yr}^{-1}$ (all $<5 \mathrm{~g}$ ) (Fig. 2E). This variability in biomass may also indicate the influence of other environmental pressures at lower dredging intensities. While the biomass of taxa such as Crepidula fornicata and Scoloplos armiger remained stable regardless of dredging intensity, high-biomass taxa such as Arctica islandica, Modiolus modiolus, Nephtys hombergii, and Alittla virens were only present at unfished sites. Significant differences in biomass between fished and unfished areas have also been observed in fully marine circalittoral scallop grounds in the Irish Sea (Kaiser et al. 2000, Hinz et al. 2011, Cook et al. 2013), suggesting that many large-bodied and longer lived individuals cannot withstand commercial dredging disturbance. Recent meta-analysis of trawling impact studies has shown biomass to be an effective indicator of trawl disturbance (Hiddink et al. 2020). Furthermore, biomass may remain responsive even under chronic trawling conditions (Reiss et al. 2009). Regular trawling disturbance typically shifts community biomass from a 
dominance of few large individuals to communities composed of abundant small macrofauna (Kaiser et al. 2000). While both large and small macrofauna are vulnerable to direct contact with fishing gear (Bergman \& Van Santbrink 2000), large-bodied and long-lived fauna are slower to recover due to their inherently low population growth rates (Jennings et al. 2001a, Queirós et al. 2006). Despite the widespread application of biomass-based indicators, there is little evidence of their use in bivalve fisheries, and in environments comparable to the study area. The sensitivity of large-bodied epifauna to mussel dredging has, however, been shown in the Limfjorden. By comparing open vs. closed areas, Dolmer (2002) revealed that areas fished 4 mo prior to fishing had reduced abundances of sponges, anthozoans, crustaceans, and ascidians compared to unfished areas. Furthermore, the species composition of epibenthos remained in an altered state in some areas for up to $4 \mathrm{yr}$ after fishing.

Changes in species composition have been observed in bivalve fisheries from the Irish Sea (Hill et al. 1999, Lambert et al. 2014), Portugal (Constantino et al. 2009), Australia (Currie \& Parry 1996), and New Zealand (Thrush et al. 1995). These shifts occur because trawling results in uneven benthic mortality, thereby altering the relative proportions of species across the community (Jennings et al. 2001b). Changes in species composition can often be subtle, and may explain why the community-level indicators such as total density did not respond to dredging, despite their effectiveness in Danish waters (Gislason et al. 2017, McLaverty et al. 2020). On the contrary, density exhibited a non-significant but positive relationship with dredging intensity. Although dredging reduced the density of many taxa in our study, high densities of opportunistic taxa were observed at the most heavily dredged sites. For example, densities of $250-500 \mathrm{~m}^{2}$ were recorded for Heteromastus filiformis, $S$. armiger, and Streblospio shrubsolii at dredging intensities of $>20 \mathrm{yr}^{-1}$ (Horsens HF01, HF04; Fig. 1). While these polychaete species can proliferate under high nutrient enrichment (Rouse \& Pleijel 2001), we would expect such high dredging intensities to significantly reduce macrofaunal density. However, a likely explanation is that dredging in these areas is characterised by highly aggregated effort (Fig. 1A-D), and thus a high degree of recovery from adjacent unaffected areas may occur via immigration between dredging events.

Although trait-based approaches have been used to effectively describe trawling impacts in shelf sea areas (Tillin et al. 2006, de Juan et al. 2007) and across large spatial scales (Lundquist et al. 2018), we were unable to detect any such functional impacts. This result was somewhat unexpected, and may indicate that unfished and dredged areas are composed of functionally similar trait combinations. Across the study area, sampling 
locations were predominantly shallow (ranging from 3-11 m depth), and physical disturbance from wind-driven waves is known to be significant at these depths (Wiles et al. 2006). Likewise, the highly eutrophic conditions will impact both fished and unfished areas. The relevance of this from a functional perspective is that shallow water communities are often naturally disturbed, and can exhibit traits associated with high functional resilience and recoverability to trawling (Bolam et al. 2017). The most widely distributed taxa in our study (e.g. Peringia ulvae, S. shrubsolii, Tubificoides benedii, Capitella sp., and Oligochaeta indet.) shared a number of traits such as generalist feeding strategies, high mobility, short longevity, and small body size. Accordingly, the abundance of these taxa and their traits were seemingly unaffected by dredging intensity. Similar functional effects of hydrodynamic disturbance (e.g. shear stress) and trawling have been observed in the relatively shallow North Sea and English Channel (van Denderen et al. 2015, Szostek et al. 2016). Our results may therefore suggest that coastal areas stressed by eutrophication can also exhibit high functional resilience and recoverability to dredge and trawl fisheries. It should be noted that this study examined functional responses to dredging at the community level, and that changes to the relative abundance of individual traits (e.g. longevity, feeding mode) may have occurred.

\subsection{Local effects of dredging}

A unique feature of our study was the examination of dredging gradients at the scale of individual N2000 sites. This revealed that the fishery-wide decline in biomass and change in species composition were not generalised across spatial scales. Community biomass decreased with dredging intensity in Horsens and Løgstør, showed little relationship in Nissum, and increased with dredging intensity in Lovns. Although populations of scavenging species can increase in response to bottom trawling disturbance (Dolmer et al. 2001, Mangano et al. 2013, González-Irusta et al. 2018), an increase in the total biomass of a community represents an unusual observation. It is likely, however, that strong environmental pressures present in Lovns may impact local community composition, and constrain our ability to accurately measure dredging effects. Due mainly to agricultural runoff, nitrogen and phosphorus loadings in Lovns are 3 times higher than average for Limfjorden (Markager et al. 2006). This added nutrient load, combined with high residence times, leads to the occurrence of regular and widespread oxygen depletion, exemplified by the 2 separate anoxic events (in June and September) that occurred in Lovns in the summer prior to sampling (Hansen 2018). It is therefore possible that hypoxic waters may have flushed into unfished 
areas of Lovns, leading to the unusually low macrofaunal abundance and biomass observed at some of these sites (e.g. LvB06, LvB08, and LvB09). Furthermore, benthic communities may have been affected by the strong temperature gradient over the year (mean temperature varied by $\pm 22^{\circ} \mathrm{C}$ ). The comparatively high benthic abundance and biomass in the dredged areas were mainly accounted for by 3 taxa: Oligochaeta indet., P. ulvae, and Petricolaria pholadiformis, all of which are relatively resilient to physical disturbance. In the southern North Sea, comparatively high densities of $P$. ulvae and $P$. pholadiformis have been observed in areas impacted by sediment dredging works (Gutperlet et al. 2015), while several studies have shown oligochaetes to be unaffected by bottom trawl disturbance (Collie et al. 2000, Fariñas-Franco et al. 2018, Sciberras et al. 2018). Although several steps were taken to exclude anoxic/hypoxic areas from our study, the dominance of stress-resilient species, variable environmental conditions, and widespread oxygen depletion in Lovns may collectively explain the apparent positive relationship between biomass and dredging intensity.

Species composition also varied significantly between unfished and dredged areas in each of the basins. In terms of density, several taxa exhibited opposing relationships with dredging. The taxa observed in higher abundance in the dredged areas were mainly gastropods or oligochaetes. Oligochaetes are pioneer species, characteristic of highly eutrophic systems, and have been observed to be the first macrofauna to recolonise heavily trawled areas (Engel \& Kvitek 1998). Although gastropods can be vulnerable to the direct effects of trawling (Ramsay et al. 2000), they are relatively mobile and can therefore exhibit fast recovery times after trawling events by migrating into the affected area (Sciberras et al. 2018). With respect to biomass-based composition, most taxa demonstrated negative responses to dredging. Although the occurrence of $A$. islandica was low, its high biomass in unfished areas was a distinguishing feature between areas. Despite its thick shell and periodic deep sediment position, $A$. islandica can experience high mortality rates due to trawling (up to $\sim 20 \%$ per trawl pass) (Bergman \& Van Santbrink 2000). This species also exhibits late maturity and slow recoverability, and is often absent from heavily fished areas. The sensitivity of A. virens and N. caeca in our study is corroborated by several other observations (Dolmer et al. 1999, Ball et al. 2000, Craeymeersch et al. 2013, Sköld et al. 2018), indicating the susceptibility of these relatively large and soft-bodied polychaetes to physical damage. 


\subsection{Auxiliary drivers}

Mussel biomass and shell hash had a strong positive effect on the structure and composition of the macrofauna. In soft-sediment habitats, hard structures such as living organisms and shell debris provide important habitat. Mussels and oysters are also capacious filter feeders, thus altering resource availability and modifying physical environmental conditions. Aggregations of mussels increase food resources, reduce turbidity via filtration, and provide hotspots of biodiversity in species-poor systems (Norling \& Kautsky 2008). In addition, empty mussel shells and shell hash provide similar benefits to benthic diversity as live mussels by providing structure, a substrate for epizoic growth, and by accumulating sediments (Norling \& Kautsky 2007). While the filtration capacity of mussel beds has been suggested as a potential mitigation tool for nutrient enrichment in the study area (Dolmer \& Frandsen 2002), the benefits of bivalve beds to associated benthic diversity and function are generally not considered. As dredging in these areas physically removes mussel and oyster biomass, and reduces quantities of shell hash (Riis et al. 2003), management may seek to examine such trade-offs to diversity and function in the future. We observed a roughly equal occurrence of mussels in samples taken in fished and unfished areas, suggesting that to some degree the potential positive effects of mussel beds were balanced across dredging intensity treatments. However, future work may seek to further investigate and quantify the interactive effects between these 2 variables.

Although community biomass was relatively similar across N2000 sites, basin was a significant predictor for several of the benthic metrics, indicating that the communities were somewhat distinct across basins. Dispersal is a key driver of community composition (Young et al. 1997), and the nestedness of these communities is likely to be determined by the degree of connectivity between basins. Aside from this relationship, salinity is also a key driver of species composition in Danish waters, and is often positively correlated with benthic species richness (Josefson \& Hansen 2004). However, we did not formally test the effects of salinity in our study due to its collinearity with other variables and the inability to improve model fits (Section 2.7). Examination of $x-y$ plots between salinity and the community indicators further validated this choice, as Nissum (the most saline basin) exhibited relatively moderate to low species and functional richness, while Horsens (the least saline) exhibited by far the highest richness. In contrast, levels of organic enrichment in the sediment were highest in Nissum and lowest in Horsens. These observations contradict our a priori assumptions regarding the 
positive relationship between salinity and benthic diversity, and suggest that these relationships may be disrupted under high eutrophication and high dredging pressure.

Sediment organic content (a proxy for eutrophication) was found to be an important driver of community density and composition in this study. Despite recent improvements under the Water Framework Directive (WFD; 2000/60/EC), eutrophication remains a significant issue in Danish coastal waters. Aside from the observed effects of nutrient enrichment to the benthos, our ability to accurately describe dredging effects was also likely hampered by the interactive effects of nutrient enrichment and oxygen depletion. Given that dissolved oxygen concentrations of the global ocean are expected to drop by $1-7 \%$ by 2100 (Schmidtko et al. 2017), scientific knowledge regarding the combined effects of trawling and low oxygen on benthic communities is considerably lacking.

\subsection{Management perspectives}

Our study has shown that it is difficult to detect fishery effects in heavily modified areas. Like many nearshore areas in Denmark, the fishing grounds examined here were characterised by high nutrient enrichment and variable environmental conditions (Conley et al. 2000). The relevance of this influence is that manmade and natural pressures can distort the outcome of fishing impact assessments, as benthic communities may become stressadapted irrespective of fishing effort (Kaiser et al. 2002). This adaptation was potentially reflected in our results from Nissum and Lovns, where the ability of indicators to detect dredging impacts were significantly impaired. Although Løgstør is also subject to nutrient enrichment and natural disturbance, a clear negative effect of dredging on macrofaunal communities was observed. This is likely due to the presence of a long-standing fisheries closure in the north of the basin, where oxygen conditions are also stable. The communities found in the closed area were comparatively less disturbed by other pressures, and as a result, provided unfished reference conditions relative to the rest of the basin. Similar reference conditions were not present in Lovns and Nissum, where dredging activities occur widely and on a rotational basis across the majority of bivalve beds. This approach is undertaken to allow the bivalves to reach marketable size prior to fishing ( $4.5 \mathrm{~cm}$ for mussels; $>80 \mathrm{~g}$ for oysters) (Frandsen et al. 2015, Nielsen \& Petersen 2019). Accordingly, most mussel beds are fished roughly every 2.5 yr (Dolmer 1998) and oysters, every 3-4 yr (Nielsen \& Petersen 2019). It is likely that few areas remain in Lovns and Nissum which are unfished, free from eutrophication and/or low oxygen conditions, and sustain bivalve beds. For this reason, the 
conservation of small reference sites could potentially improve ecological monitoring and fisheries management in these areas by providing suitable and permanent 'control' areas adjacent to the fishing grounds (Lindeboom 1995). Such a strategy would not require the closure of large areas or entire basins. As we have shown, reference sites (and associated sensitive macrofauna) can be maintained in close proximity ( 100 m) to high-intensity dredging (Fig. 1A,D). The inclusion of reference sites into future monitoring studies could also help meet several conservation and management objectives of the fishery, improve local habitat diversity and function, as well as potentially reduce the need to implement large sampling programs to inform ecosystem-based management advice. Finally, the preservation of reference areas can support a management scenario where shifting baselines are not ignored (Brown \& Trebilco 2014).

Acknowledgements. Thanks to Jens Würgler Hansen, Aarhus University, for providing oxygen depletion maps of the study area. Thanks to Pernille Nielsen and Camille Saurel, both the Danish Shellfish Centre, for discussions regarding the planning of field work and interpretation of results. Thanks to Daniel van Denderen for advice regarding the planning of the study. Thanks to Jeppe Olsen for providing black-box data and associated shapefiles. We thank the captains of the RV 'Egon P': Lars Kyed Andersen and Finn Bak, and to Kasper Lenda Andersen, Louise Scherffenberg Lundgaard, and Stine Kærulf Andersen for assistance during field work. Thanks to the several student assistants for laboratory assistance in sorting benthic samples into higher taxonomic groups. Finally, we thank the 3 reviewers for their helpful comments and suggestions. This study was funded by The Danish Fisheries Agency, Ministry of Environment and Food of Denmark, through the European Maritime and Fisheries Fund (EMFF) via the project 'Påvirkning af økosystemkomponenten bundfauna i N2000 områder ved fiskeri med skrabende redskaber' (grant agreement number 33-113B-16056) and DTU Aqua. 


\section{REFERENCES}

Amoroso RO, Pitcher CR, Rijnsdorp AD, McConnaughey RA and others (2018) Bottom trawl fishing footprints on the world's continental shelves. Proc. Natl. Acad. Sci. USA 115:E10275-E10282 PubMed. doi:10.1073/pnas.1802379115.

Anderson MJ, Gorleyt RN, Clarket KR (2008) PERMANOVA + for PRIMER : t. Guide to Software Stats Methods 1:186.

Anon (1979) Birds directive: Council Directive of 2 April 1979 on the conservation of wild birds (79/409/EEC). Off. J. Eur. Union. L. 103:1-18.

Anon (1992) Habitats directive: Council Directive 92/43/EEC of 21 May 1992 on the conservation of natural habitats and of wild fauna and flora. Off. J. Eur. Union. L. 206:750 .

Ball BJ, Fox G, Munday BW (2000) Long- and short-term consequences of a Nephrops trawl fishery on the benthos and environment of the Irish Sea. ICES J. Mar. Sci. 57:1315-1320. doi:10.1006/jmsc.2000.0924.

Barton K (2013) MuMIn: multi-model inference. R package version 1.40.4. https://cran.rproject.org/web/packages/MuMIn/index.html.

Bergman MJN, Van Santbrink JW (2000) Mortality in megafaunal benthic populations caused by trawl fisheries on the Dutch continental shelf in the North Sea in 1994. ICES. J. Mar. Sci. 57:1321-1331.

Bolam SG, Garcia C, Eggleton J, Kenny AJ and others (2017) Differences in biological traits composition of benthic assemblages between unimpacted habitats. Mar. Environ. Res. 126:1-13 PubMed. doi:10.1016/j.marenvres.2017.01.004.

Brooks ME, Kristensen K, van Benthem KJ, Magnusson A and others (2017) glmmTMB balances speed and flexibility among packages for zero-inflated generalized linear mixed modelling. R. J. 9:378-400. doi:10.32614/RJ-2017-066.

Brown CJ, Trebilco R (2014) Unintended cultivation, shifting baselines, and conflict between objectives for fisheries and conservation. Conserv. Biol. 28:677-688. PubMed. doi:10.1111/cobi.12267.

Burnham KP, Anderson D (2002) Model selection and multimodel inference: a practical information-theoretical approach, 2nd edn. Springer-Verlag, New York, NY. 
Burnham KP, Anderson DR (2004) Multimodel inference: understanding AIC and BIC in model selection. Sociol. Methods Res. 33:261-304. doi:10.1177/0049124104268644.

Clarke, K.R., Gorley, R.N., 2015. Primer v7: user manual/tutorial. PRIMER-E Ltd, Plymouth.

Collie JS, Hall SJ, Kaiser MJ, Poiner IR (2000) A quantitative analysis of fishing impacts shelf-sea benthos. J. Anim. Ecol. 69:785-798 PubMed. doi:10.1046/j.13652656.2000.00434.x.

Conley DJ, Kaas H, Møhlenberg F, Rasmussen B, Windolf J, Mohlenberg F, Windolf J (2000) Characteristics of Danish estuaries. Estuaries 23:820-837. doi:10.2307/1353000.

Constantino R, Gaspar MB, Tata-Regala J, Carvalho S and others (2009) Clam dredging effects and subsequent recovery of benthic communities at different depth ranges. Mar Environ. Res. 67:89-99 PubMed. doi:10.1016/j.marenvres.2008.12.001.

Cook R, Fariñas-Franco JM, Gell FR, Holt RHF and others (2013) The substantial first impact of bottom fishing on rare biodiversity hotspots: a dilemma for evidence-based conservation. PLOS ONE 8:e69904 PubMed.

Craeymeersch J, Jansen J, Smaal A, van Stralen M, Meesters E, Fey F (2013) Impact of mussel seed fishery on subtidal macrozoobenthos in the western Wadden Sea. IMARES report no. PR 7 C003/13. Institute for Marine Resources \& Ecosystem Studies, Yerseke.

Currie DR, Parry GD (1996) Effects of scallop dredging on a soft sediment community: a large-scale experimental study. Mar. Ecol. Prog. Ser. 134:131-150. doi:10.3354/meps134131.

de Juan S, Demestre M (2012) A Trawl Disturbance Indicator to quantify large scale fishing impact on benthic ecosystems. Ecol. Indic. 18:183-190.

de Juan S, Thrush SF, Demestre M (2007) Functional changes as indicators of trawling disturbance on a benthic community located in a fishing ground (NW Mediterranean Sea). Mar. Ecol. Prog. Ser. 334:117-129.

DHI (2013) MIKE 21 \& MIKE 3 Flow Model FM. Hydrodynamic and Transport Module. Scientific Documentation. DHI Water Environment Health, Hørsholm. 
Diesing M, Stephens D, Aldridge J (2013) A proposed method for assessing the extent of the seabed significantly affected by demersal fishing in the Greater North Sea. ICES. J. Mar. Sci. 70:1085-1096. doi:10.1093/icesjms/fst066.

Dinesen GE, Timmermann K, Roth E, Markager S and others (2011) Mussel production and water framework directive targets in the Limfjord, Denmark: an integrated assessment for use in system-based management. Ecol. Soc. 16:art26. doi:10.5751/ES-04259-160426.

Dolmer P (1998) Seasonal and spatial variability in growth of Mytilus edulis L. in a brackish sound: comparisons of individual mussel growth and growth of size classes. Fish. Res. 34:17-26. doi:10.1016/S0165-7836(97)00081-7.

Dolmer P (2002) Mussel dredging: impact on epifauna in Limfjorden, Denmark. J. Shellfish Res. 21:529-538.

Dolmer P, Christensen H, Hansen B, Vismann B (2012) Area-intensive bottom culture of blue mussels Mytilus edulis in a micro-tidal estuary. Aquac. Environ. Interact. 3:81-91.

Dolmer P, Frandsen RP (2002) Evaluation of the Danish mussel fishery: suggestions for an ecosystem management approach. Helgol. Mar. Res. 56:13-20 doi:10.1007/s10152-0010095-6.

Dolmer P, Hoffmann E (2004) Østersfiskeri i Limfjorden - sammenligning af redskaber. Danmarks Fiskeriundersøgelser, Charlottenlund.

Dolmer P, Sand Kristensen P, Hoffmann E (1999) Dredging of blue mussels (Mytilus edulis L.) in a Danish sound: stock sizes and fishery-effects on mussel population dynamic. Fish. Res. 40:73-80. doi:10.1016/S0165-7836(98)00218-5.

Dolmer P, Kristensen T, Christiansen ML, Petersen MF, Kristensen PS, Hoffmann E (2001) Short-term impact of blue mussel dredging. Hydrobiologia 465:115-127. doi:10.1023/A:1014549026157.

Dormann CF, Elith J, Bacher S, Buchmann C, Carl G, Carré G, Marquéz JRG, Gruber B, Lafourcade B, Leitão PJ, Münkemüller T, McClean C, Osborne PE, Reineking B, Schröder B, Skidmore AK, Zurell D, Lautenbach S (2013) Collinearity: a review of methods to deal with it and a simulation study evaluating their performance. Ecography (Cop) 36:27-46. 
Eigaard OR, Bastardie F, Breen M, Dinesen GE and others (2016) Estimating seabed pressure from demersal trawls, seines, and dredges based on gear design and dimensions. ICES. J. Mar. Sci. 73:i27-i43. doi:10.1093/icesjms/fsv099.

Eigaard OR, Bastardie F, Hintzen NT, Buhl-Mortensen L and others (2017) The footprint of bottom trawling in European waters: distribution, intensity, and seabed integrity. ICES. J. Mar. Sci. 74:847-865.

Engel J, Kvitek R (1998) Effects of otter trawling on a benthic community in Monterey Bay National Marine Sanctuary. Conserv. Biol. 12:1204-1214. doi:10.1046/j.15231739.1998.0120061204.x.

FAO 2016. The State of World Fisheries and Aquaculture 2016. Contributing to food security and nutrition for all. FAO, Rome. 200 pp.

Fariñas-Franco JM, Allcock AL, Roberts D (2018) Protection alone may not promote natural recovery of biogenic habitats of high biodiversity damaged by mobile fishing gears. Mar. Environ. Res. 135:18-28 PubMed. doi:10.1016/j.marenvres.2018.01.009.

Frandsen RP, Eigaard OR, Poulsen LK, Tørring D, Stage B, Lisbjerg D, Dolmer P (2015) Reducing the impact of blue mussel (Mytilus edulis) dredging on the ecosystem in shallow water soft bottom areas. Aquat. Conserv. 25:162-173. doi:10.1002/aqc.2455.

Frandsen RP, Dolmer P (2002) Effects of substrate type on growth and mortality of blue mussels (Mytilus edulis) exposed to the predator Carcinus maenas. Mar. Biol. 141:253262.

Gislason H, Sinclair M, Sainsbury K, O’Boyle R (2000) Symposium overview: incorporating ecosystem objectives within fisheries management. ICES. J. Mar. Sci. 57:468-475.

Gislason H, Bastardie F, Dinesen GE, Egekvist J, Eigaard OR (2017) Lost in translation? Multi-metric macrobenthos indicators and bottom trawling. Ecol. Indic. 82:260-270. doi:10.1016/j.ecolind.2017.07.004.

Gutperlet R, Capperucci RM, Bartholomä A, Kröncke I (2015) Benthic biodiversity changes in response to dredging activities during the construction of a deep-water port. Mar Biodivers. 45:819-839. doi:10.1007/s12526-014-0298-0.

González-Irusta JM, De la Torriente A, Punzón A, Blanco M, Serrano A (2018) Determining and mapping species sensitivity to trawling impacts: the BEnthos Sensitivity Index to Trawling Operations (BESITO). ICES. J. Mar. Sci. 75:1710-1721. 
Hall-Spencer JM, Moore PG (2000) Impact of scallop dredging on maerl grounds. In: Kaiser MJ, De Groot SJ (eds) Effects of fishing on non-target species and habitats: biological, conservation and socio-economic issues. Blackwell Science, Oxford, p 105-118.

Hansen JW (2018) Marine områder 2016: NOVANA. Videnskabelig rapport nr. 253 fra DCE - Nationalt Center for Miljø og Energi. http://dce2.au.dk/pub/SR253.pdf.

Hartig F (2016) DHARMa: residual diagnostics for hierarchical (multi-level/mixed) regression models. DHARMa version 0.2.0. https://cran.rproject.org/web/packages/DHARMa/index.html.

Hiddink JG, Jennings S, Kaiser MJ, Queirós AM, Duplisea DE, Piet GJ (2006) Cumulative impacts of seabed trawl disturbance on benthic biomass, production, and species richness in different habitats. Can. J. Fish. Aquat. Sci. 63:721-736 doi:10.1139/f05-266.

Hiddink JG, Jennings S, Sciberras M, Szostek CL and others (2017) Global analysis of depletion and recovery of seabed biota after bottom trawling disturbance. Proc. Natl. Acad. Sci. USA 114:8301-8306 PubMed. doi:10.1073/pnas.1618858114.

Hiddink JG, Kaiser MJ, Sciberras M, McConnaughey RA and others (2020) Selection of indicators for assessing and managing the impacts of bottom trawling on seabed habitats. J. Appl. Ecol. 57:619-629. doi:10.1111/1365-2664.13617.

Hill AS, Veale LO, Pennington D, Whyte SG, Brand AR, Hartnoll RG (1999) Changes in Irish Sea benthos: possible effects of 40 years of dredging. Estuar. Coast. Shelf. Sci. 48:739-750. doi:10.1006/ecss.1999.0476.

Hinz H, Tarrant D, Ridgeway A, Kaiser MJ, Hiddink JG (2011) Effects of scallop dredging on temperate reef fauna. Mar. Ecol. Prog. Ser. 432:91-102. doi:10.3354/meps09166.

Hinz H, Moranta J, Balestrini S, Sciberras M and others (2017) Stable isotopes reveal the effect of trawl fisheries on the diet of commercially exploited species. Sci. Rep. 7:6334 PubMed. doi:10.1038/s41598-017-06379-6.

Hoffmann E, Dolmer P (2000) Effect of closed areas on distribution of fish and epibenthos. ICES J. Mar. Sci. 57:1310-1314. doi:10.1006/jmsc.2000.0921. Jennings S, Kaiser MJ (1998) The effects of fishing on marine ecosystems. Adv. Mar. Biol. 34:201-352. doi:10.1016/S0065-2881(08)60212-6. 
Jennings S, Dinmore TA, Duplisea DE, Warr KJ, Lancaster JE (2001a) Trawling disturbance can modify benthic production processes. J. Anim. Ecol. 70:459-475. doi:10.1046/j.13652656.2001.00504.x.

Jennings S, Pinnegar JK, Polunin NVC, Warr KJ (2001b) Impacts of trawling disturbance on the trophic structure of benthic invertebrate communities. Mar. Ecol. Prog. Ser. 213:127142. doi:10.3354/meps213127.

Jennings S, Nicholson MD, Dinmore TA, Lancaster JE (2002) Effects of chronic trawling disturbance on the production of infaunal communities. Mar. Ecol. Prog. Ser. 243:251260. doi:10.3354/meps243251.

Jørgensen BB, Jorgensen BB (1980) Seasonal oxygen depletion in the bottom waters of a Danish fjord and its effect on the benthic community. Oikos 34:68-76. doi:10.2307/3544551.

Josefson AB, Hansen JLS (2004) Species richness of benthic macrofauna in Danish estuaries and coastal areas. Glob. Ecol. Biogeogr. 13:273-288. doi:10.1111/j.1466822X.2004.00091.x.

Kristensen, PS \& Hoffmann, E 2000, Fiskeri efter blåmuslinger i Danmark 1989-1999. DFUrapport, no. 72-00, Danmarks Fiskeriundersøgelser. Afdelingen for Havfiskeri, Charlottenlund.

Kaiser MJ, Ramsay K, Richardson CA, Spence FE, Brand AR (2000) Chronic fishing disturbance has changed shelf sea benthic community structure. J. Anim. Ecol. 69:494503. doi:10.1046/j.1365-2656.2000.00412.x.

Kaiser MJ, Collie JS, Hall SJ, Jennings S, Poiner IR (2002) Modification of marine habitats by trawling activities: prognosis and solutions. Fish. Fish. 3:114-136. doi:10.1046/j.14672979.2002.00079.x.

Kaiser MJ, Clarke KR, Hinz H, Austen MCV, Somerfield PJ, Karakassis I (2006) Global analysis of response and recovery of benthic biota to fishing. Mar. Ecol. Prog. Ser. 311:114. doi:10.3354/meps311001.

Kaiser MJ, Hormbrey S, Booth JR, Hinz H, Hiddink JG (2018) Recovery linked to life history of sessile epifauna following exclusion of towed mobile fishing gear. J. Appl. Ecol. 55:1060-1070. doi:10.1111/1365-2664.13087. 
Kutner MH, Nachtscheim CJ, Neter J, Li W (2004) Applied linear statistical models. McGraw-Hill/Irwin, New York, NY.

Lambert GI, Jennings S, Kaiser MJ, Davies TW, Hiddink JG (2014) Quantifying recovery rates and resilience of seabed habitats impacted by bottom fishing. J. Appl. Ecol. 51:1326-1336. doi:10.1111/1365-2664.12277.

Lambert GI, Murray LG, Hiddink JG, Hinz H and others (2017) Defining thresholds of sustainable impact on benthic communities in relation to fishing disturbance. Sci. Rep. 7:5440 PubMed. doi:10.1038/s41598-017-04715-4.

Legendre P, Andersson MJ (1999) Distance-based redundancy analysis: testing multispecies responses in multifactorial ecological experiments. Ecol. Monogr. 69:1-24. doi:10.1890/0012-9615(1999)069[0001:DBRATM]2.0.CO;2.

Lindeboom HJ (1995) Protected areas in the North Sea: An absolute need for future marine research. Helgoländer Meeresuntersuchungen 49:591-602.

Lüdecke D (2016) sjPlot: data visualization for statistics in social science. http://cran.rproject.org/package $=$ sjPlot.

Lundquist CJ, Bowden D, Cartner K, Stephenson F, Tuck I, Hewitt JE (2018) Assessing benthic responses to fishing disturbance over broad spatial scales that incorporate high environmental variation. Front. Mar. Sci. 5:405. doi:10.3389/fmars.2018.00405.

Maar M, Timmermann K, Petersen JK, Gustafsson KE, Storm LM (2010) A model study of the regulation of blue mussels by nutrient loadings and water column stability in a shallow estuary, the Limfjorden. J. Sea. Res. 64:322-333. doi:10.1016/j.seares.2010.04.007.

MacArthur RH, Wilson EO (1967) The theory of island biogeography. Princeton University Press, Princeton, NJ.

Mangano M, Kaiser MJ, Porporato EMD, Spanò N (2013) Evidence of trawl disturbance on mega-epibenthic communities in the Southern Tyrrhenian Sea. Mar. Ecol. Prog. Ser. 475:101-117. doi:10.3354/meps10115.

Markager S, Storm LM, Stedmon CA (2006) Limfjordens miljøtilstand 1985 til 2003. Sammenhæng mellem næringsstoftilførsler, klima og hydrografi belyst ved hjælp af empiriske modeller. Faglig rapport fra DMU nr. 577. Danmarks Miljøundersøgelser, Arahus. 
Markager S, Bassompierre M, Petersen DJ (2010) Analyse af miljøtilstanden i Horsens Fjord fra 1985 til 2006. Empirisk modellering. Faglig rapport fra DMU nr. 733. Danmarks Miljøundersøgelser, Arahus.

McLaverty C, Eigaard OR, Gislason H, Bastardie F and others (2020) Using large benthic macrofauna to refine and improve ecological indicators of bottom trawling disturbance. Ecological Indicators 110:105811. https://doi.org/10.1016/j.ecolind.2019.105811.

Ministry of Foreign Affairs of Denmark (2019) Målsætninger og forvaltningsprincipper for muslinge- og østersskrab og øvrig muslinge- og østersproduktion i og udenfor Natura 2000 områder. www.fiskeristyrelsen.dk/erhvervsfiskeri/saerlige-fiskerier/muslinger-ogoesters/muslinge-og-oesterspolitikken/.

Moritz C, Gravel D, Savard L, McKindsey CW, Brêthes JC, Archambault P (2015) No more detectable fishing effect on Northern Gulf of St Lawrence benthic invertebrates. ICES J. Mar. Sci. 72:2457-2466. doi:10.1093/icesjms/fsv124.

Nielsen P, Petersen JK (2019) Flat oyster fishery management during a time with fluctuating population size. Aquat. Living. Resour. 32:22. doi:10.1051/alr/2019020.

Nielsen P, Canal-Vergés P, Nielsen MM, Geitner K, Petersen JK (2017)

Konsekvensvurdering af fiskeri efter blåmuslinger ved og øst for Horsens Fjord samt Endelave 2017. DTU Aqua rapport nr. 319-2017. Institut for Akvatiske Ressourcer, Charlottenlund.

Norling P, Kautsky N (2007) Structural and functional effects of Mytilus edulis on diversity of associated species and ecosystem functioning. Mar. Ecol. Prog. Ser. 351:163-175. doi:10.3354/meps07033.

Norling P, Kautsky N (2008) Patches of the mussel Mytilus sp. are islands of high biodiversity in subtidal sediment habitats in the Baltic sea. Aquat. Biol. 4:75-87. doi:10.3354/ab00096.

Olsgard F, Schaanning MT, Widdicombe S, Kendall MA, Austen MC (2008) Effects of bottom trawling on ecosystem functioning. J. Exp. Mar. Biol. Ecol. 366:123-133. doi:10.1016/j.jembe.2008.07.036.

Piet GJ, Quirijns FJ (2009) The importance of scale for fishing impact estimations. Can. J. Fish. Aquat. Sci. 66:829-835. 
Queirós AM, Hiddink JG, Kaiser MJ, Hinz H (2006) Effects of chronic bottom trawling disturbance on benthic biomass, production and size spectra in different habitats. J. Exp. Mar. Biol. Ecol. 335:91-103. doi:10.1016/j.jembe.2006.03.001.

Ramsay K, Kaiser M, Richardson C, Veale L, Brand A (2000) Can shell scars on dog cockles (Glycymeris glycymeris L.) be used as an indicator of fishing disturbance? J. Sea. Res. 43:167-176. doi:10.1016/S1385-1101(00)00006-X.

Reiss H, Greenstreet SPR, Sieben K, Ehrich S, Piet GJ, Quirijns F, Robinson L, Wolff WJ, Kröncke I (2009) Effects of fishing disturbance on benthic communities and secondary production within an intensively fished area. Mar. Ecol. Prog. Ser. 394:201-213.

Riemann B, Hoffmann E (1991) Ecological consequences of dredging and bottom trawling in the Limfjord, Denmark. Mar. Ecol. Prog. Ser. 69:171-178. doi:10.3354/meps069171.

Riis A, Dolmer P, Riis A (2003) The distribution of the sea anemone Metridium senile (L.) related to dredging for blue mussels (Mytilus edulis L.) and flow habitat. Ophelia 57:4352. doi:10.1080/00785236.2003.10409504.

Rouse G, Pleijel F (2001) Polychaetes. Oxford university press, Oxford.

Schmidtko S, Stramma L, Visbeck M (2017) Decline in global oceanic oxygen content during the past five decades. Nature 542:335-339 PubMed. doi:10.1038/nature21399.

Sciberras M, Hinz H, Bennell JD, Jenkins SR, Hawkins SJ, Kaiser MJ (2013) Benthic community response to a scallop dredging closure within a dynamic seabed habitat. Mar. Ecol. Prog. Ser. 480:83-98. doi:10.3354/meps10198.

Sciberras M, Hiddink JG, Jennings S, Szostek CL and others (2018) Response of benthic fauna to experimental bottom fishing: a global meta-analysis. Fish. Fish. 19:698-715. doi:10.1111/faf.12283.

Sköld M, Göransson P, Jonsson P, Bastardie F and others (2018) Effects of chronic bottom trawling on soft-seafloor macrofauna in the Kattegat. Mar. Ecol. Prog. Ser. 586:41-55. doi:10.3354/meps 12434 .

Szostek CL, Murray LG, Bell E, Rayner G, Kaiser MJ (2016) Natural vs. fishing disturbance: drivers of community composition on traditional king scallop, Pecten maximus, fishing grounds. ICES J. Mar. Sci. 73:i70-i83. doi:10.1093/icesjms/fsv152. 
Thrush SF, Hewitt JE, Cummings VJ, Dayton PK (1995) The impact of habitat disturbance by scallop dredging on marine benthic communities: What can be predicted from the results of experiments? Mar. Ecol. Prog. Ser. 129:141-150. doi:10.3354/meps129141.

Tillin HM, Hiddink JG, Jennings S, Kaiser MJ (2006) Chronic bottom trawling alters the functional composition of benthic invertebrate communities on a sea-basin scale. Mar. Ecol. Prog. Ser. 318:31-45. doi:10.3354/meps318031.

Tomczak MT, Dinesen GE, Hoffmann E, Maar M, Støttrup J (2013) Integrated trend assessment of ecosystem changes in the Limfjord (Denmark): Evidence of a recent regime shift? Estuar. Coast. Shelf Sci. 117:178-187. doi:10.1016/j.ecss.2012.11.009.

van Denderen PD, Bolam SG, Hiddink JG, Jennings S, Kenny A, Rijnsdorp AD, van Kooten $\mathrm{T}$ (2015) Similar effects of bottom trawling and natural disturbance on composition and function of benthic communities across habitats. Mar. Ecol. Prog. Ser. 541:31-43. doi:10.3354/meps 11550 .

Villéger S, Mason NWH, Mouillot D (2008) New multidimensional functional diversity indices for a multifaceted framework in functional ecology. Ecology 89:2290-2301 PubMed. doi:10.1890/07-1206.1.

Wiens JA (1989) Spatial scaling in ecology. Funct. Ecol. 3:385-397.

Wiles PJ, van Duren LA, Haëse C, Larsen J, Simpson JH (2006) Stratification and mixing in the Limfjorden in relation to mussel culture. J. Mar. Syst. 60:129-143. doi:10.1016/j.jmarsys.2005.09.009.

Young CM, Sewell MA, Tyler PA, Metaxas A (1997) Biogeographic and bathymetric ranges of Atlantic deep-sea echinoderms and ascidians: the role of larval dispersal. Biodivers. Conserv. 6:1507-1522. doi:10.1023/A:1018314403123. 
Table 1. Dominant taxa in terms of density and biomass. Occurrence (\%) indicates the percentage occurrence of taxa across all samples

\begin{tabular}{|c|c|c|c|c|c|}
\hline Taxa & Count & $\begin{array}{c}\text { Occurrence } \\
(\%)\end{array}$ & Taxa & $\begin{array}{c}\text { Biomass } \\
(\mathrm{g})\end{array}$ & $\begin{array}{c}\text { Occurrence } \\
(\%)\end{array}$ \\
\hline Mytilus edulis ${ }^{\mathrm{a}}$ & 2817 & 65 & Mytilus edulis ${ }^{\mathrm{a}}$ & 4532.7 & 65 \\
\hline Peringia ulvae & 1430 & 45.5 & Arctica islandica & 239.4 & 3 \\
\hline Streblospio shrubsolii & 1145 & 81.8 & Asterias rubens $\mathrm{a}^{\mathrm{a}}$ & 115.3 & 18.2 \\
\hline Tubificoides benedii & 1141 & 45.5 & Carcinus maenas ${ }^{\mathrm{a}}$ & 88.9 & 33.3 \\
\hline Capitella sp. & 1035 & 48.5 & Crepidula fornicata & 78.2 & 33.3 \\
\hline Petricolaria pholadiformis & 1027 & 18.2 & Modiolus modiolus & 73.2 & 3 \\
\hline Oligochaeta indet. & 1003 & 78.8 & Petricolaria pholadiformis & 46.3 & 18.2 \\
\hline Kurtiella bidentata & 1002 & 87.9 & Tritia reticulata & 12.9 & 27.3 \\
\hline Scoloplos armiger & 666 & 72.7 & Aporrhais pespelecani & 12.2 & 9.1 \\
\hline Heteromastus filiformis & 510 & 39.4 & Alitta virens & 8.2 & 45.5 \\
\hline Corbula gibba & 472 & 30.3 & Venerupis corrugata & 7.3 & 3 \\
\hline Nephtys hombergii & 459 & 72.7 & Peringia ulvae & 6.5 & 45.5 \\
\hline Bittium reticulatum & 457 & 24.2 & Littorina littorea & 5.6 & 6.1 \\
\hline Microdeutopus sp. & 389 & 72.7 & Psammechinus miliaris & 5.6 & 12.1 \\
\hline Mediomastus sp. & 385 & 51.5 & Mya arenaria & 5.0 & 15.2 \\
\hline Pygospio elegans & 315 & 57.6 & Nephtys hombergii & 4.1 & 72.7 \\
\hline Polydora cornuta & 294 & 60.6 & Echinoidea & 2.7 & 6.1 \\
\hline Monocorophium insidiosum & 292 & 63.6 & Ensis leei & 2.6 & 3 \\
\hline
\end{tabular}

${ }^{a}$ Excluded from the formal analysis

Table 2. Generalised linear mixed models of macrofaunal indicators, showing the importance of each predictor in the model as represented by relative variable importance scores. $(+)$ Positive relationships; (-) negative relationships. Statistically significant parameters are shown in bold. Conditional $\mathrm{R}^{2}$ values describe the proportion of variance explained by both fixed and random terms in the model. LOI: loss on ignition

\begin{tabular}{|lccccccccc|}
\hline $\begin{array}{l}\text { Community } \\
\text { indicator }\end{array}$ & Basin & $\begin{array}{c}\text { Basin } \times \\
\text { Dredging }\end{array}$ & Dredging & LOI & $\begin{array}{c}\text { Mussel } \\
\text { biomass }\end{array}$ & $\begin{array}{c}\text { Shell } \\
\text { hash }\end{array}$ & Current & Depth & $\begin{array}{c}\text { Conditional } \\
\mathrm{R}^{2}\end{array}$ \\
\hline Density & $\mathbf{1 . 0 0}$ & 0.07 & $0.36(+)$ & $\mathbf{0 . 9 6}(-)$ & $\mathbf{0 . 9 3}(+)$ & $\mathbf{0 . 6 8}(+)$ & $0.37(-)$ & $0.43(+)$ & 0.83 \\
Biomass & 1.00 & $\mathbf{0 . 4 9}$ & $\mathbf{0 . 6 2}(-)$ & $0.40(-)$ & $0.54(+)$ & $\mathbf{0 . 7 1 ( + )}$ & $0.32(+)$ & $0.49(+)$ & 0.38 \\
Functional richness & $\mathbf{1 . 0 0}$ & 0.09 & $0.27(-)$ & $0.29(-)$ & $\mathbf{0 . 9 9}(+)$ & $0.53(+)$ & $0.29(+)$ & $0.44(+)$ & 0.78 \\
\hline
\end{tabular}

Table 3. Percentage of community variance explained by dredging and environmental predictors. Variance partitioning derived from distance-based linear models of community composition. Total variance explained by the model is provided by the $\mathrm{R}^{2}$. LOI: loss on ignition. -: non-significant term not included in final model. 


\begin{tabular}{|lcccccccc|}
\hline $\begin{array}{l}\text { Community } \\
\text { composition }\end{array}$ & Dredging & LOI & $\begin{array}{c}\text { Mussel } \\
\text { biomass }\end{array}$ & $\begin{array}{c}\text { Shell } \\
\text { hash }\end{array}$ & Current & Depth & Basin & $\mathrm{R}^{2}$ \\
\hline Density & 3.3 & 5.5 & 5.4 & 3.3 & 1.3 & 9.5 & 21.3 & 49.6 \\
Biomass & 2.5 & 3.3 & 2.4 & 2.1 & - & 4.9 & 7.5 & 23.9 \\
Traits & - & - & 4.2 & 1.5 & - & 2.4 & 10.4 & 18.5 \\
\hline
\end{tabular}

Table 4. (A) Results of 2-way PERMANOVA models, testing for differences in community composition between basins and between unfished and dredged areas. (B) Pairwise tests between pairs of 'unfished vs. dredged'. Significant p-values are indicated in bold. Tests were based on 999 permutations

\begin{tabular}{|lcccccc|}
\hline & \multicolumn{2}{c}{ Density } & \multicolumn{2}{c}{ Biomass } & \multicolumn{2}{c|}{ Traits } \\
\cline { 2 - 6 } & Pseudo- $F$ & $\mathrm{p}$ & Pseudo- $F$ & $\mathrm{p}$ & Pseudo- $F$ & $\mathrm{p}$ \\
\hline (A) 2-way analysis & \multicolumn{1}{c}{} & & & & \\
Basin & 22.61 & $\mathbf{0 . 0 0 1}$ & 6.53 & $\mathbf{0 . 0 0 1}$ & 4.22 & $\mathbf{0 . 0 0 1}$ \\
Dredging & 2.79 & $\mathbf{0 . 0 0 1}$ & 1.70 & $\mathbf{0 . 0 2 7}$ & 1.77 & 0.094 \\
Basin $\times$ dredging & 3.25 & $\mathbf{0 . 0 0 1}$ & 2.11 & $\mathbf{0 . 0 0 1}$ & 1.27 & 0.186 \\
\multicolumn{2}{l}{} & & & & & \\
(B) Pairwise comparisons (unfished vs. dredged) & & & & \\
Horsens & 2.33 & $\mathbf{0 . 0 0 1}$ & 1.61 & $\mathbf{0 . 0 0 2}$ & - & - \\
Løgstør & 1.13 & $\mathbf{0 . 0 0 1}$ & 1.41 & $\mathbf{0 . 0 2 5}$ & - & - \\
Lovns & 2.20 & $\mathbf{0 . 0 0 1}$ & 1.85 & $\mathbf{0 . 0 0 4}$ & - & - \\
Nissum & 1.44 & $\mathbf{0 . 0 4 1}$ & 1.20 & 0.134 & - & - \\
\hline
\end{tabular}


Table 5. Similarity percentages analysis describing the species with the greatest contribution to observed dissimilarity between unfished and dredged areas. Species are

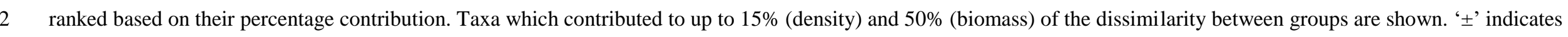

3 if density/biomass was higher (A) or lower $(\boldsymbol{\nabla})$ in dredged areas. Cum. contrib.: cumulative contribution to dissimilarity between fishing effort; fished/unfished: mean

4 density/biomass of taxa in fished and unfished areas. HF: Horsens Fjord; LB: Løgstør Broad; LvB: Lovns Broad; NB: Nissum Broad

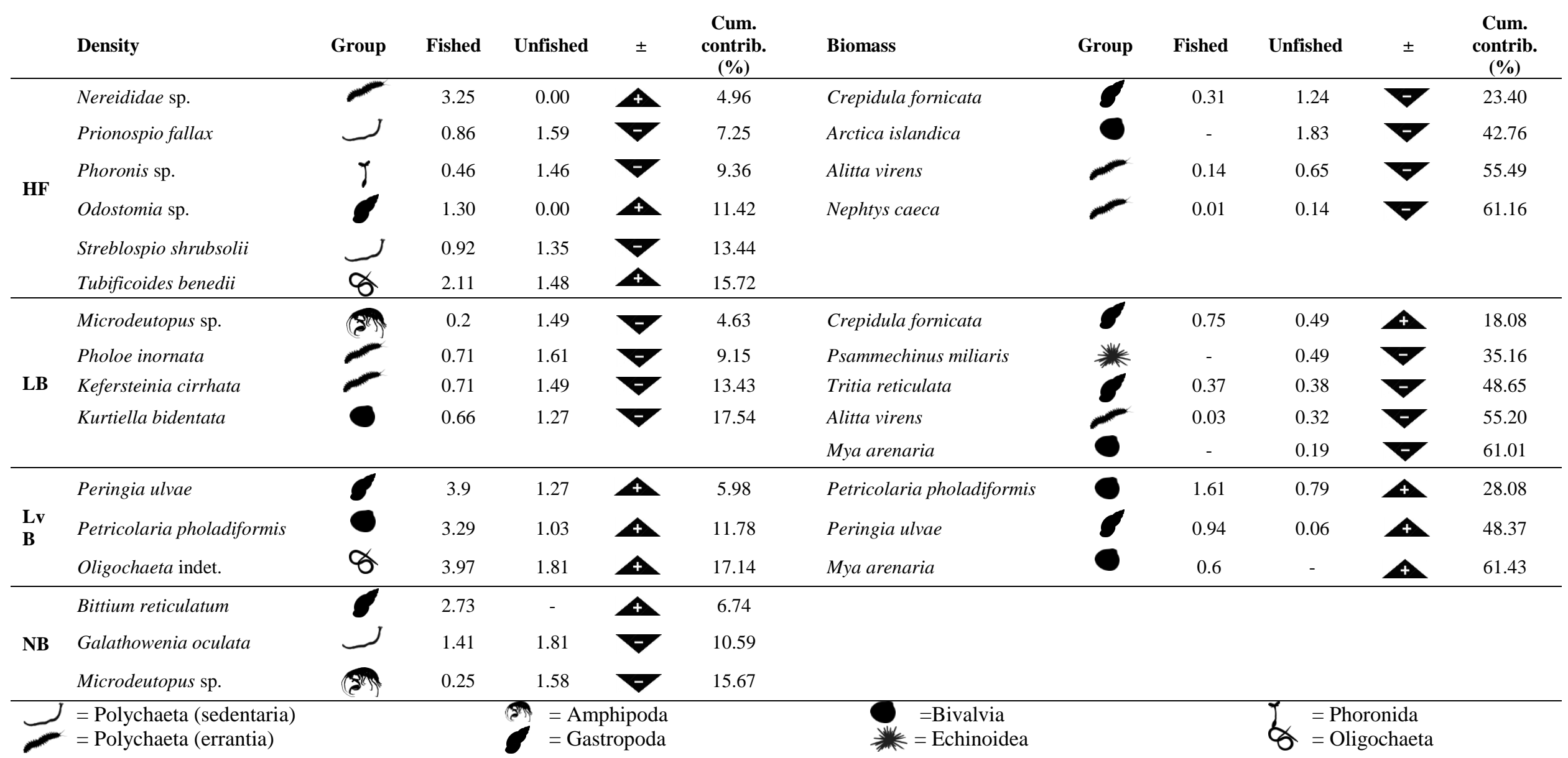




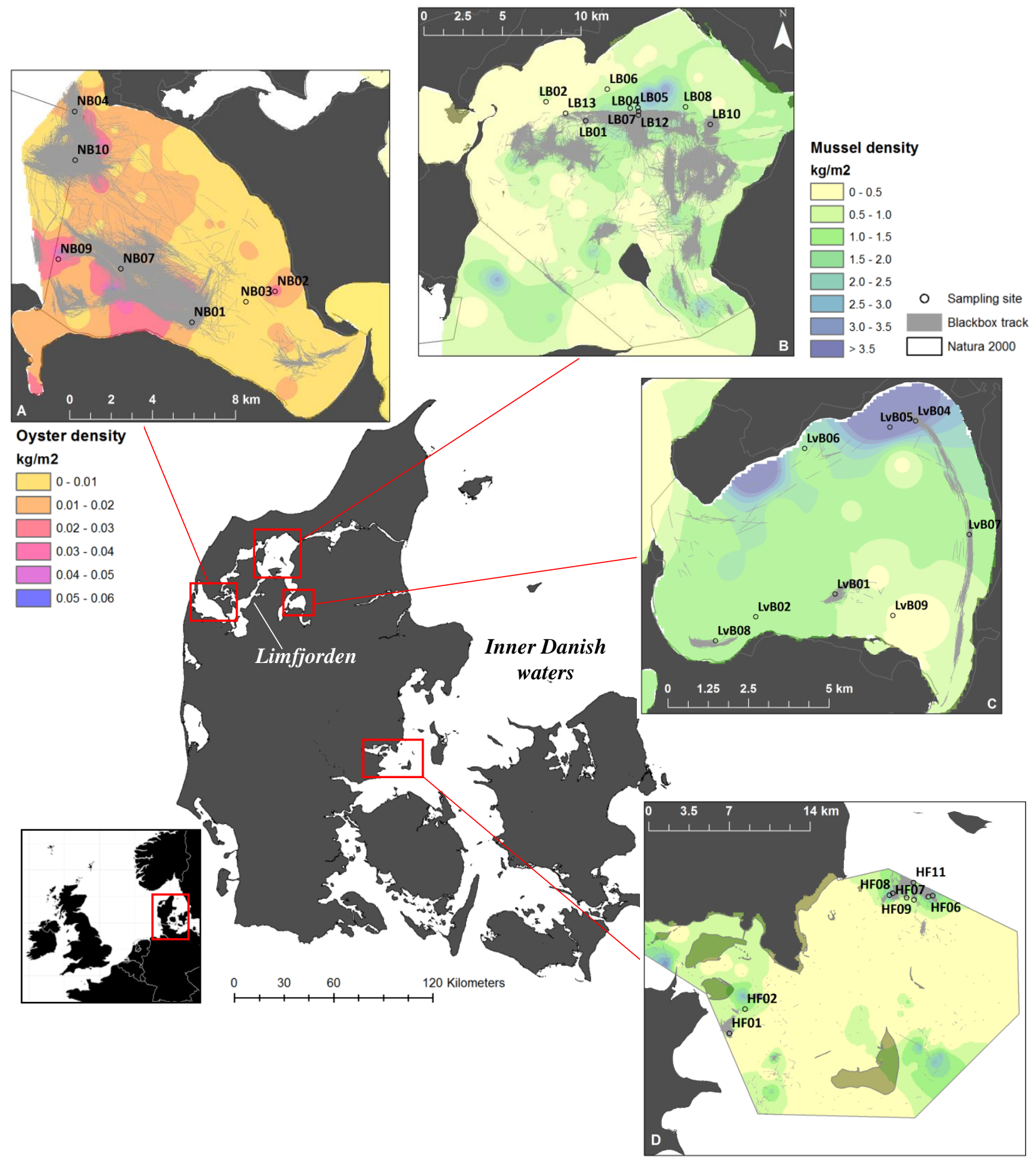

6 Fig. 1. Sampling effort across the 4 Natura 2000 sites: (A) Nissum Broad, (B) Løgstør Broad,

7 (C) Lovns Broad, and (D) Horsens Fjord. The black-box tracks represent the footprint of

8 individual hauls. Estimated mussel and oyster densities are based on annual bivalve stock

9 monitoring surveys. 
(A)

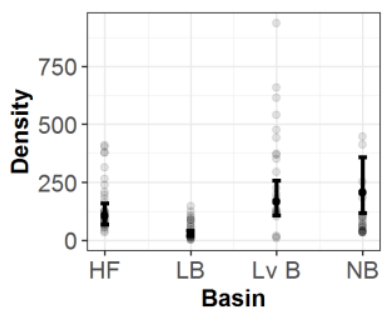

(E)

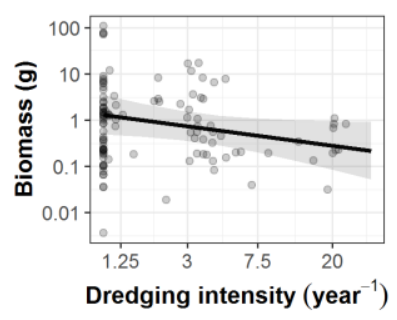

(G)

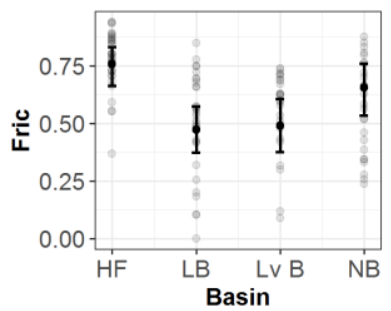

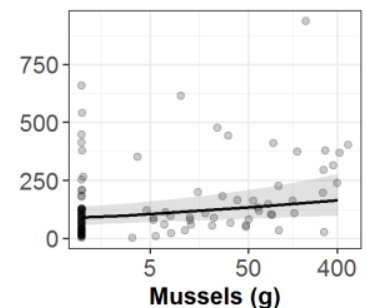

$(\mathrm{F})$

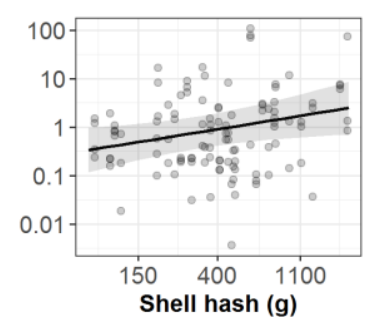

(H)

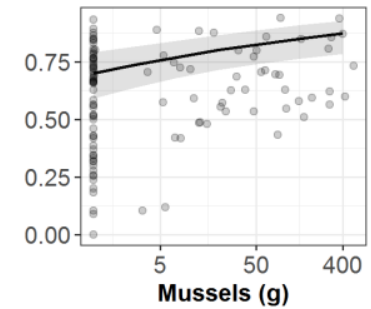

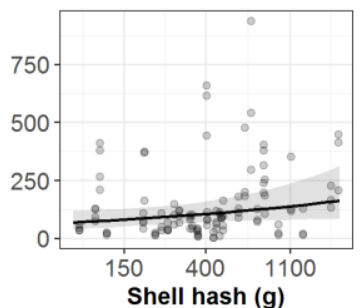

(D)

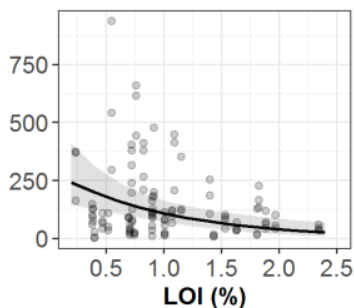

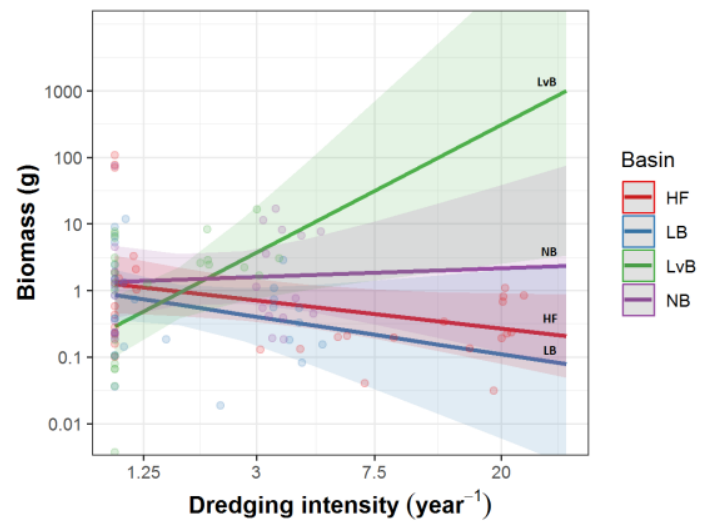

Fig. 2. Marginal effect of significant predictors on (A-D) density, $(\mathrm{E}, \mathrm{F}, \mathrm{I})$ biomass, and $(\mathrm{G}, \mathrm{H})$

12 Fric. Regression lines: predicted values from generalised linear mixed models; shaded areas: 95\% CI. Note that the axes for biomass, dredging intensity, mussels, and shell hash are presented on a natural logarithmic scale. Fric: functional richness; HF: Horsens Fjord; LB: 